\title{
Factors governing the human immune response to injected insulin
}

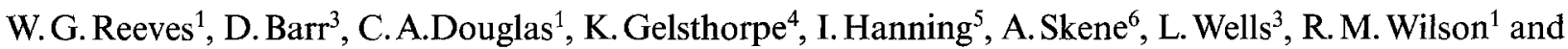 \\ R.B. Tattersall ${ }^{2}$ \\ Departments of ${ }^{1}$ Immunology and ${ }^{2}$ Medicine, University Hospital, Queen's Medical Centre, Nottingham, Tissue Typing Laboratories, \\ ${ }^{3}$ Birmingham and ${ }^{4}$ Sheffield Regional Blood Transfusion Services, ${ }^{5}$ Department of Clinical Biochemistry and Metabolic Medicine, \\ Royal Victoria Infirmary, Newcastle and ${ }^{6}$ Department of Mathematics, University of Nottingham, UK
}

Summary. Seventy-nine patients were observed prospectively
during their initial period of treatment with conventional bo-
vine insulins. Insulin antibody levels 6 months after starting
insulin therapy did not correlate with age, gender or $\beta$ cell
function at onset of treatment. Patients who required soluble
insulin in addition to isophane insulin developed higher levels
of insulin antibody. Patients bearing the HLA-B $8, D R 3$ and
C4AQO alleles had lower levels of insulin antibody, whereas
those bearing DR 7 produced significantly higher levels. Other
alleles at the C4A, C4B, C 2 , factor B or Gm loci did not ap- pear to have a significant effect on insulin antibody production. The hyporesponsiveness of B 8/DR3/C4AQO-positive individuals probably reflects a non-specific abnormality of immunity whereas the enhanced responsiveness of those positive for DR 7 suggests the presence of a specific immune response gene for insulin

Key words: Insulin, insulin antibody, immunogenicity, immune response genes, haemocyanin, HLA, DR 7, C2, C4, factor B, Gm, C-peptide.
Diabetic individuals differ widely in their antibody response to injected insulin and there are likely to be several reasons for these variations in immunogenicity $[1,2]$. Constitutional factors are clearly important as some patients fail to respond to the more immunogenic bovine preparations [3]. There have been few attempts to examine the relative contribution of these different variables but several retrospective studies of clinic populations of insulin-dependent diabetic patients suggest a link between low antibody response to insulin and possession of HLA-B 8 and DR3 [4-6]. We decided, therefore, to mount a prospective study of new insulinrequiring diabetic patients treated with conventional bovine insulin preparations, to examine the importance of genetic and other factors in determining the magnitude of the immune response to insulin.

\section{Subjects and methods}

\section{Subjects}

Seventy-nine patients of Caucasoid origin, in whom a clinical decision had been made to start insulin treatment, were recruited to the Nottingham prospective study. There were 45 men and 34 women whose ages ranged from 14 to 82 years (mean 40 years). Classification of diabetes into Types 1 and 2 remains to matter of considerable dispute and we had difficulty in assigning some of the patients in this study. It is easy to say that someone has Type 1 (insulin-dependent) diabetes if he or she presents in ketoacidosis but much more difficult to classify a young thin patient in whom diagnosis is made and treatment started before ketonuria has developed. For the purposes of the present study, we have categorised as Type 1 those patients who had had symptoms for less than 6 weeks and/or had ketonuria (more than ++ on Ketosticks: Ames, Indianapolis Indiana, USA) or had positive islet cell antibody. Patients with none of these features were designated Type 2 (non-insulin-dependent) unless they had some other cause of diabetes, e.g.: chronic pancreatitis or maturity-onset type diabetes of the young (MODY). On this basis, 54 patients had Type 1, 20 Type 2 and five had diabetes due to other causes. Of the 20 patients classified as Type 2, eleven were less than 60 years of age at diagnosis. Blood samples were taken before starting insulin (and in the presence of considerable hyperglycaemia) for determination of serum C-peptide concentrations and to confirm the absence of insulin antibody. All patients were treated with bovine insulin preparations purified by sequential recrystallisation (i. e. contaminated with $\sim 1000 \mathrm{ppm}$ proinsulin): 58 received isophane alone, 17 isophane with an acid soluble preparation and four lente insulin. Most patients were started on insulin as outpatients under the supervision of diabetes nurse practitioners. Soluble insulin was added if post-prandial hyperglycaemia was not controlled. Blood samples were taken for insulin antibody determination at 1, 3 and 6 months after commencing insulin therapy. Patients attended for a special visit between 3 and 6 months after entry when full HLA, C2, C4, factor B and Gm typing was performed.

\section{Methods}

IgG insulin antibody reactive with ${ }^{125}$ I-labelled bovine insulin was measured as described previously [3]. Insulin was removed from sera prior to assay and results expressed in $\mu \mathrm{g} / 1$ without subtraction for 

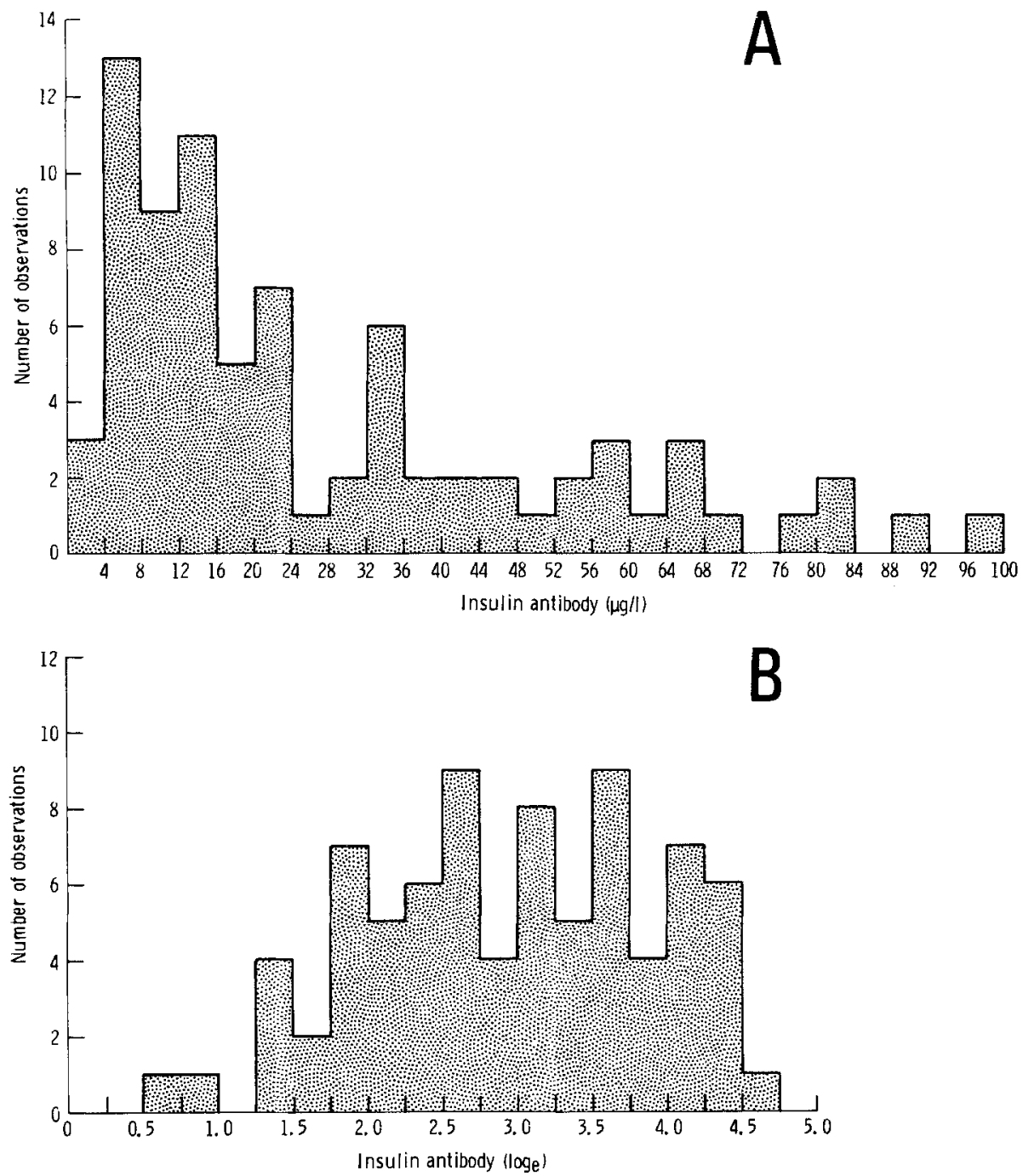

Fig. $1 \mathrm{~A}$ and B. Insulin antibody levels 6 months after starting insulin treatment: $A$ arithmetical distribution, $\mathbf{B} \log _{\mathrm{e}}$ distribution

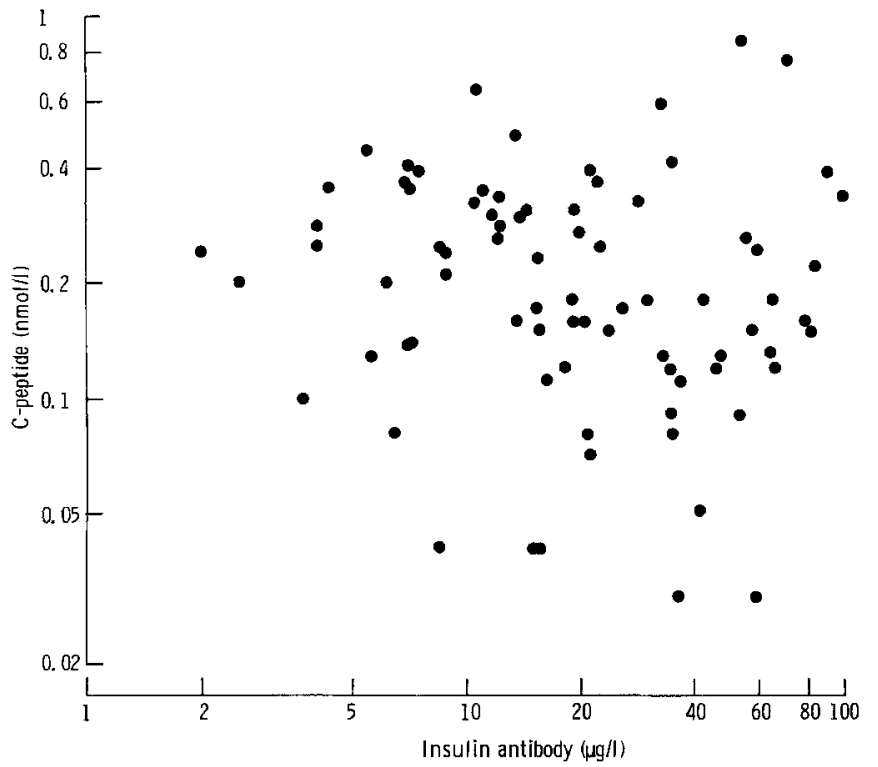

Fig. 2. Log-log plot of C-peptide levels before starting insulin treatment against insulin antibody levels occurring 6 months later normal serum binding [7]. Circulating C-peptide levels were determined by radioimmunoassay and expressed in $\mathrm{nmol} / 1$ [8]. Islet cell antibodies were sought by indirect immunofluorescence using cryostat sections of unfixed human group 0 pancreas [9]. HLA typing at $A$, $\mathrm{B}$ and $\mathrm{C}$ loci was performed using a standard microlymphocytotoxicity assay with reagents specific for the following alleles: A1, 2, 3, 9, 10 $(25+26), 11,28,29, w 30, w 31, w 32, w 33 ; B 5,7,8,12(w 44+w 45)$, $13,14,15$, w16 (w 38 +w39), 17, 18, w 21 (w $49+w 50)$, w 22, 27, w 35, 37, 40, w41, w 47; Cw1, w 2, w3, w 4, w 5, w6 and w7. DR typing was performed on B lymphocytes purified by E-rosette depletion [10] with reagents specific for DR 1, 2, 3, 4, 5, w6, 7 and w9. C2 allotypes $\mathrm{B}, \mathrm{C}$ and null were detected using isoelectric focussing with a haemolytic overlay [11]. The following C4 and factor B (Bf) allotypes were determined using high voltage electrophoresis in agarose with immunofixation: $\mathrm{C} 4 \mathrm{~A}-1,2,3,4,5,6$ and $\mathrm{QO}, \mathrm{C} 4 \mathrm{~B}-1,2,3$ and $\mathrm{QO}, \mathrm{Bf}-\mathrm{F}, \mathrm{F} 1$, $\mathrm{S}$ and $\mathrm{S} 1[12,13]$. The nomenclature for $\mathrm{C} 4$ is as agreed at the Fourth International Complement Workshop [14]. Gm typing was performed by haemagglutination inhibition [15] using reagents specific for the following allotypic markers: $\operatorname{IgG}_{1}(\mathrm{a}, \mathrm{x}, \mathrm{z}$ and $\mathrm{f}), \operatorname{IgG}_{2}(\mathrm{n})$ and $\operatorname{IgG}_{3}$ (b and g) obtained from the Central Laboratory, Dutch Red Cross Blood Transfusion Service, Amsterdam, The Netherlands.

\section{Statistical analysis}

The statistical analysis used standard Student's t-test and analysis of variance techniques to identify subgroups with different mean anti- 

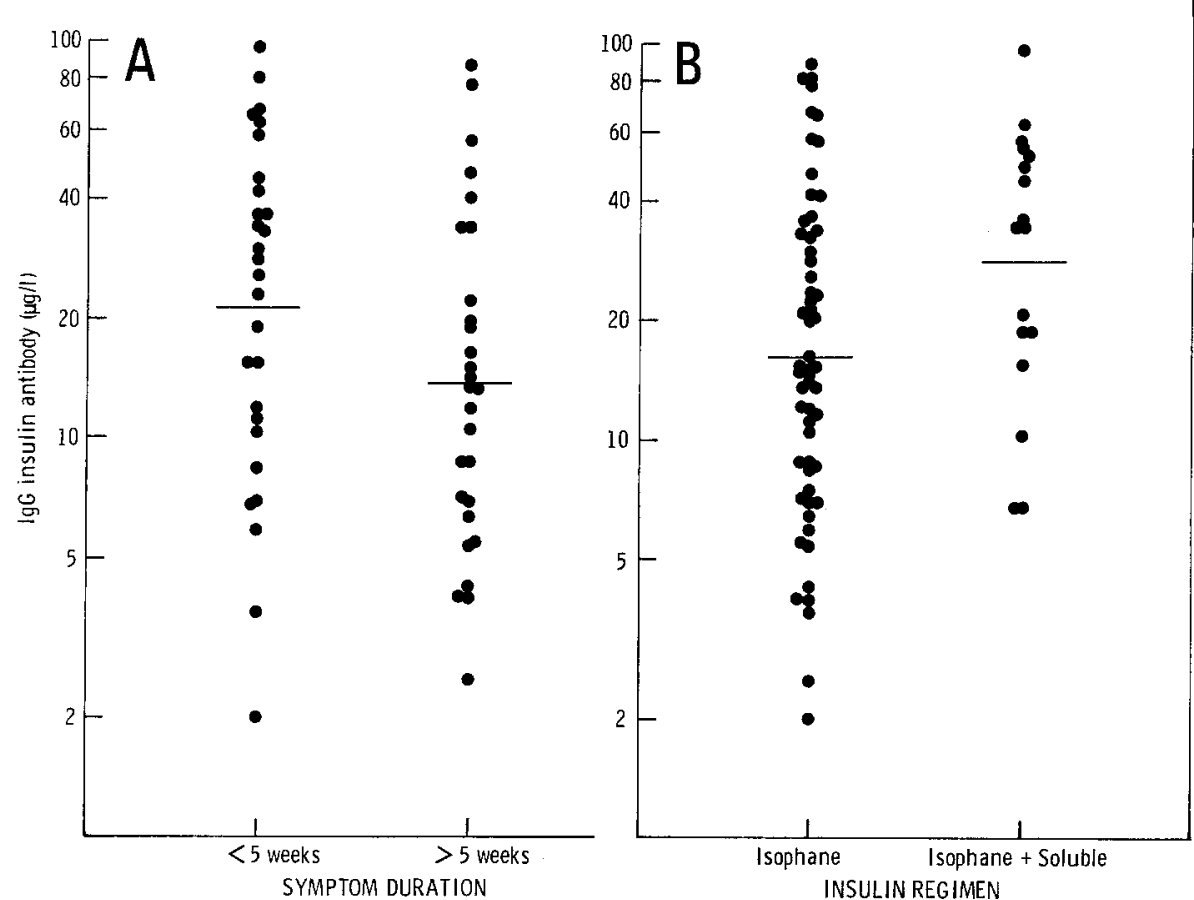

Fig.3. A Insulin antibody levels in patients who had acute symptoms for $>5$ weeks versus $<5$ weeks before starting insulin treatment. B Insulin antibody levels in patients treated with isophane insulin alone versus those requiring soluble insulin in additon

Table 1. Insulin antibody levels for patients possessing or lacking alleles detected at HLA-B and HLA-DR loci

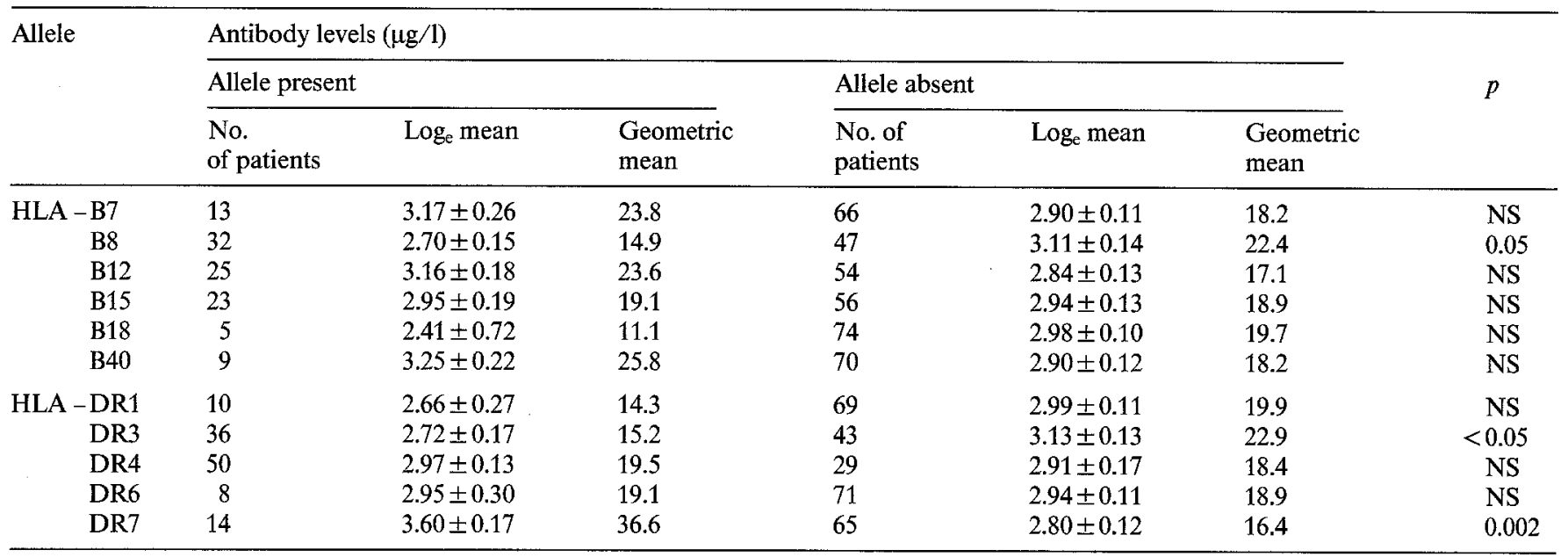

$\log _{\mathrm{e}}$ results expressed as mean \pm SEM. NS $=$ not significant

body levels. Initial $\log _{\mathrm{e}}$ transformation of the data was necessary to ensure that the assumptions implicit in these procedures were satisfied. Results are thus expressed in terms of $\log _{e}$ mean $\pm S E M$, as well as geometric means on the original measurement scale.

\section{Results}

The distribution of insulin antibody levels 6 months after starting insulin therapy is strongly positively skewed (Fig.1 A), whereas $\log _{e}$-transformation gives a fairly symmetrical distribution (Fig.1B). Figure 2 is a log-log plot of C-peptide levels before starting insulin treatment against insulin antibody levels 6 months later and it shows the lack of relationship between these two parameters. There was also no relationship between age or gender and the level of insulin antibody achieved. Accurate knowledge of duration of symptoms prior to starting insulin was available on 56 patients, of whom 28 had had symptoms for less than 5 weeks and 28 for longer than this (Fig. 3 A). The difference between these two groups is not significant at the $5 \%$ level. Patients who required soluble insulin in addition to isophane generally showed a higher insulin antibody level $(p<$ 0.05 , Fig. 3 B). The group numbers and insulin antibody levels for patients possessing each of the more common HLA-B and HLA-DR alleles detected in this population are set out in Table 1 and compared in each case with the remaining patients who lack each allele. Individuals bearing HLA-B 8 and DR 3 have lower insulin antibody levels ( $p=0.05$ and $<0.05$, respectively), 
Table 2. Comparison of insulin antibody levels for DR7 positive versus negative individuals belonging to different groups of patients

\begin{tabular}{|c|c|c|c|c|c|c|c|}
\hline \multirow[t]{2}{*}{ Groups } & \multicolumn{6}{|c|}{ Antibody levels $(\mu \mathrm{g} / 1)$} & \multirow{2}{*}{$p$} \\
\hline & $\begin{array}{l}\text { No. } \\
\text { of patients }\end{array}$ & $\log _{e}$ mean & $\begin{array}{l}\text { Geometric } \\
\text { mean }\end{array}$ & $\begin{array}{l}\text { No. of } \\
\text { patients }\end{array}$ & $\log _{e}$ mean & $\begin{array}{l}\text { Geometric } \\
\text { mean }\end{array}$ & \\
\hline $\begin{array}{l}\text { Patients with diabetes } \\
\text { Type } 1(n=54)\end{array}$ & 7 & $3.30 \pm 0.22$ & 27.1 & 47 & $2.77 \pm 0.13$ & 16.0 & 0.15 \\
\hline Whole group $(n=79)$ & 14 & $3.60 \pm 0.17$ & 36.6 & 65 & $2.80 \pm 0.12$ & 16.4 & 0.002 \\
\hline
\end{tabular}

$\log _{\mathrm{e}}$ results expressed as mean $\pm \mathrm{SEM}$

Table 3. Insulin antibody levels for patients possessing certain phenotypes at the $\mathrm{C} 2$, factor $\mathrm{B}, \mathrm{C} 4 \mathrm{~A}, \mathrm{C} 4 \mathrm{~B}$ and $\mathrm{Gm}$ loci

\begin{tabular}{|c|c|c|c|c|c|c|c|c|}
\hline & \multicolumn{7}{|c|}{ Antibody levels $(\mu \mathrm{g} / 1)$} & \multirow{2}{*}{$p$} \\
\hline & $\begin{array}{l}\text { No. } \\
\text { of patients }\end{array}$ & $\log _{e}$ mean & $\begin{array}{l}\text { Geometric } \\
\text { mean }\end{array}$ & & $\begin{array}{l}\text { No. } \\
\text { of patients }\end{array}$ & $\log _{\mathrm{e}}$ mean & $\begin{array}{l}\text { Geometric } \\
\text { mean }\end{array}$ & \\
\hline $\mathrm{C} 2 \mathrm{C}$ & 68 & $2.92 \pm 0.11$ & 18.5 & $\mathrm{C} 2 \mathrm{~B} / \mathrm{C}$ & 10 & $3.15 \pm 0.29$ & 23.3 & NS \\
\hline $\mathrm{Bf} \mathrm{S}$ & 55 & $2.86 \pm 0.12$ & 17.5 & Bf S/other ${ }^{b}$ & 24 & $3.13 \pm 0.19$ & 22.9 & NS \\
\hline $\mathrm{Gm} \mathrm{fb}$ & 36 & $2.77 \pm 0.14$ & 16.0 & & & & & \\
\hline $\mathrm{fb} / \mathrm{ag}$ & 32 & $3.07 \pm 0.17$ & 21.5 & e & & & & NS \\
\hline $\mathrm{ag}$ & 11 & $3.17 \pm 0.31$ & 23.8 & $\int$ & & & & \\
\hline $\mathrm{Gm} n+$ & 48 & $2.88 \pm 0.13$ & 17.8 & $\mathrm{n}$ & 31 & $3.04 \pm 0.18$ & 20.9 & NS \\
\hline$x+$ & 18 & $3.12 \pm 0.21$ & 22.7 & $\mathrm{x}-$ & 61 & $2.89 \pm 0.12$ & 18.0 & NS \\
\hline
\end{tabular}

$\log _{e}$ results expressed as mean $\pm \mathrm{SEM} . \mathrm{NS}=$ not significant

${ }^{a}$ The one remaining individual was $\mathrm{C} 20{ }^{\mathrm{b}}{ }^{\mathrm{b}}$ these patients consisted of $20 \mathrm{~S} / \mathrm{F}, 3 \mathrm{~S} / \mathrm{F} 1$ and one $\mathrm{S} / \mathrm{S} 1 ;^{\mathrm{c}}$ these were: $51 \mathrm{~A} 3,11 \mathrm{~A} 3 /$ other, nine $\mathrm{A} 4$ and three miscellaneous; ${ }^{d}$ these were: $13 \mathrm{~B} 1 / \mathrm{B} 3,13 \mathrm{~B} 1 / \mathrm{B} 2$ and 10 miscellaneous. ${ }^{\mathrm{e}}$ one-way analysis of variance failed to detect any difference between phenotype means

whereas those possessing DR 7 show significantly higher levels of insulin antibody $(p=0.002)$. The presence or absence of DR 4 did not correlate with insulin antibody levels. $p$ values are for comparisons between groups possessing or lacking each allele. If the $p$ value for the DR association is corrected for the number of alleles examined according to the method of Edwards [16] (i. e. $p_{\mathrm{c}}=1-(1-p)^{\mathrm{n}}$ where $\left.n=5\right)$ then $p_{\mathrm{c}}$ values for the DR3 and DR 7 associations become, respectively, 0.23 and 0.01 . The DR7 association is thus unambiguous but would not have been detected using the present data if patients with diabetes of other than Type 1 had been excluded (Table 2). Although the geometric mean for patients with Type 1 diabetes bearing DR 7 is higher than for those who lack this allele, this difference is not statistically significant and it is not until all data are analysed that an association, significant after correction for the number of alleles examined, is established.

Table 3 lists antibody levels for patients bearing different phenotypes at the C2, C4, factor B and Gm loci. The only association observed is a link between possession of the C4AQO allele and a reduced antibody re- sponse to insulin and this allele was present in association with HLA-B 8 and DR 3 in each case. Twenty-three patients possessed the DR3/DR4 phenotype and thus had a consistent genotype at the DR locus. These patients were examined separately for any effect of polymorphism at the complement or immunoglobulin allotype loci. No further associations were detected.

\section{Discussion}

The insulin antibody data obtained 6 months after starting insulin therapy (Fig.1) confirm the wide heterogeneity of response and positively skewed distribution described previously [3, 17]. However, $\log _{\mathrm{e}}$ transformation gives an acceptably symmetrical distribution and therefore we analysed the insulin antibody response as a continuous variable rather than compartmenting it into low and high categories with an arbitrary threshold in between. We have shown previously that most insulin antibodies induced by bovine insulin therapy are specific for determinants shared by the endogenous human 
molecule [3]. There is evidence to suggest that the ease with which the natural state of tolerance to self proteins is broken is determined by the level of such proteins present in the circulation [18]. It therefore seemed important to investigate a possible relationship between the level of insulin antibody production and the level of $\beta$ cell function at the time insulin therapy was instituted. However, we find no relationship between $\beta$ cell function - as evidenced by serum C-peptide levels - and insulin antibody production 6 months thereafter (Fig. 2). Our patients covered a wide age range (although children were excluded) but there was no evidence of any association between insulin antibody production and age or gender. Patients varied considerably in their duration of symptoms of diabetes before starting insulin treatment but this did not have a significant effect on insulin antibody production. Those patients who required soluble insulin in addition to isophane did, however, show a significant enhancement of antibody production (Fig. 3). This is in keeping with the fact that soluble preparations of conventional bovine insulin also induce greater levels of antibody reactive with C-peptide and pancreatic polypeptide $[19,20]$.

The association of HLA-B 8 and DR 3 with low levels of insulin antibody production has been recorded previously [4-6], but these studies were retrospective and patients either had received a mixture of insulin species or the species used was not identified. Our finding of an association between HLA-DR7 and an increased level of insulin antibody production is new and rather more striking. Our policy was to include all patients started on insulin without restricting recruitment to those with Type 1 diabetes. Although HLA-DR 3 and DR 4 are much more common in Type 1 diabetes, HLADR 2 and DR 7 are much less common than in the general population [21] and the association with DR7 would not have been observed if we had restricted our study to patients with Type 1 diabetes (Table 2).

The $\mathrm{C} 2, \mathrm{C} 4$ and factor $\mathrm{B}$ loci lie between HLA-DR and HLA-B on chromosome 6. Possession of the allele $\mathrm{C} 4 \mathrm{AQO}$ associated with low responses to insulin and all five patients with this allele possessed HLA-B8 and DR 3 in addition. These alleles are positively associated and frequently co-exist as part of a common haplotype [22]. No other associations were observed between the magnitude of insulin antibody responses and individual alleles at the $\mathrm{C} 2, \mathrm{C} 4$ and factor $\mathrm{B}$ loci. The 23 DR 3/DR 4 heterozygotes in whom a consistent genotype had been established at the DR locus seemed an ideal subgroup in which to examine further the possible influence of variation at the C2, C4 and factor B loci. However, this too did not reveal any other significant associations.

Nakao et al. [23] reported an association between variation at the $\mathrm{IgG} \mathrm{Gm}$ allotype locus on chromosome 14 and insulin antibody responsiveness. Gm typing in our study did not reveal a significant association for the group as a whole or the sub-population of 23
DR3/DR 4 heterozygotes. However, the Gm data presented in Table 3 do show a consistent trend with ag homozygotes giving the highest mean value, $f b$ homozygotes the lowest and $a g / f b$ heterozygotes an intermediate value. The $x$ positive group also gives a higher mean value than the group of $x$ negative individuals. This result is in keeping with the overall finding of Nakao et al. [23] that the Gm 1, 2, 21 (i. e. xag) haplotype is associated with the presence of insulin antibody, although the cut off point which they used to distinguish between 'presence' and 'absence' of insulin antibody was not defined. Further studies are required to substantiate this association.

The DR7 association with elevated antibody responses to insulin appears to be independent of genes at the other HLA loci. However, a previous study on patients with insulin allergy [24] did describe an association with DR7, Bw 44 and A2 but antibody levels were not reported and their patients were of mixed ethnic origin and diabetes type.

Immune response genes for insulin have been documented in mice and guinea pigs [25-27] although there is debate concerning their site of action [28]. It seems likely that DR7 identifies an immune response gene governing the human antibody response to injected insulin and the fact that the antibody response to an immunising injection of Helix pomatia haemocyanin (given to 47 patients from this same population) does not show a similar correlation is in support of this (unpublished observations). The immune response gene may be DR7 itself or a gene in linkage disequilibrium with it - possibly at the adjoining SB or DC loci [29]. DR 3 may identify an immune suppression gene [30] although the association with a non-functional complement allotype (C4AQO) plus evidence that individuals bearing the $\mathrm{B} 8 / \mathrm{DR} 3$ haplotype are less able to clear immune complexes, may indicate a non-specific abnormality of immunity [31].

HLA-DR 7 associates with coeliac disease, dermatitis herpetiformis and persistent lymphocytosis [32-34] and further study of specific immune responses that associate with DR7 should tell us more about the pathogenesis of these and other DR-related diseases.

Acknowledgements. We thank Drs. S. Allison, K. Gurling, D. Hosking, W. Jeffcoate, R. Lloyd-Mostyn and K. Sands for allowing us to study patients under their care; Sisters P.Clarke and H. Barkes for invaluable assistance throughout the study; Drs. A. Campbell and P. van der Minne for help with patient visits and documentation; P. Mackintosh for helpful discussion; R. Mackay for dispensing standard insulins; J.Sykes for help with insulin antibody measurement and A. Bowdler for organisational assistance and for typing the manuscript. We are grateful to Nordisk-UK and Novo Laboratories for financial support.

\section{References}

1. Reeves WG (1980) Immunology of diabetes and insulin therapy. In: Thompson RA (ed) Recent advances in clinical immunology. Churchill Livingstone, Edinburgh, pp 183-220 
2. Reeves WG (1983) Insulin antibody determination: theoretical and practical considerations. Diabetologia 24: 399-403

3. Reeves WG, Kelly U (1982) Insulin antibodies induced by bovine insulin therapy. Clin Exp Immunol 50: 163-170

4. Bertrams J, Jansen FK, Gruneklee D, Reis HE, Drost H, Beyer J, Gries FA, Kuwert E (1976) HLA antigens and immunoresponsiveness to insulin in insulin-dependent diabetes mellitus. Tissue Antigens 8: 13-19

5. Irvine WJ, Di Mario U, Feek CM Ting A, Morris PJ, Gray RS, Duncan LJP (1978) Insulin antibodies in relation to islet cell antibodies and HLA antigens in insulin-dependent (Type I) diabetes. J Clin Lab Immunol 1: 111-114

6. Schernthaner G, Ludwig H, Mayr WR (1979) Immunoglobulin Ginsulin antibodies and immune region-associated alloantigens in insulin-dependent diabetes mellitus. J Clin Endocrinol Metab 48: 403-407

7. Reeves WG, Kelly U (1980) An immunochemical method for the quantitation of insulin antibodies. J Immunol Meth 34: 329-338

8. Heding LG (1975) Radioimmunological determination of human C-peptide in serum. Diabetologia 11: 541-548

9. Bottazzo GF, Florin-Christensen A, Doniach D (1974) Islet cell antibodies in diabetes mellitus with autoimmune polyendocrine deficiencies. Lancet 2: 1279-1283

10. Gelsthorpe K, Doughty RW (1977) B lymphocyte preparation and typing in less than four hours. Tissue Antigens 10:236

11. Meo T, Atkinson J, Bernoco M, Bernoco D, Ceppellini R (1976) Mapping of the HLA locus controlling $\mathrm{C} 2$ structural variants and linkage disequilibrium between alleles $\mathrm{C} 2.2$ and Bw 15. Eur J Immunol 6:916-919

12. Awdeh ZL, Alper CA (1980) Inherited structural polymorphism of the fourth component of complement (C4). Proc Natl Acad Sci $77: 3576-3580$

13. Alper CA, Boenisch T, Watson L (1972) Genetic polymorphism in human glycine-rich beta-glycoprotein. J exp Med 135: 68-80

14. Mauff G, Alper CA, Awdeh Z, Batchelor JR, Bertrams J, BruunPetersen G, Dawkins RL, Demant P, Edwards J, Grosse-Wilde H, Hauptmann G, Klouda P, Lamm L, Mollenhauer E, Nerl C, Olaisen B, O'Neill G, Rittner C, Roos MH, Skanes V, Teisberg P, Wells L (1983) Statement on the nomenclature of human C4 allotypes. Immunobiology 164: 184-191

15. Grubb R (1970) The genetic markers of human immunoglobulins. Springer, New York

16. Edwards JH (1974) HLA and disease: the detection of associations. J Immunogenet 1: 249-257

17. Heding LG, Larsson $Y$, Ludvigsson J (1980) The immunogenicity of insulin preparations. Antibody levels before and after transfer to highly purified porcine insulin. Diabetologia 19: 511-515

18. Weigle WO, Morgan EL, Thoman ML (1982) Activation of lymphocytes in immunity and tolerance. In: Weigle WO (ed) Advances in immunopathology. Elsevier/North Holland, Amsterdam, pp 49-83

19. Reeves WG, Douglas CA (1982) C-peptide antibodies induced by bovine insulin therapy. Clin Exp Immunol 50: 171-177

20. Reeves WG (1981) Antibody production during insulin therapy patterns of response and clinical sequels. In: Keck K, Erb P (eds)
Basic and clinical aspects of immunity to insulin. Walter de Gruyter, Berlin, pp 219-235

21. Svejgaard A, Platz P, Ryder LP (1980) Insulin-dependent diabetes mellitus. In: Terasaki PI (ed) Histocompatibility testing. UCLA Tissue Typing Laboratory, Los Angeles, pp 638-656

22. Dawkins RL, Christiansen FT, Kay PH, Garlepp M, McCluskey J, Hollingsworth PN, Zilko PJ (1983) Disease associations with complotypes, supratypes and haplotypes. In: Moller G (ed) Immunological reviews 70, Munksgaard, Copenhagen, pp 5-22

23. Nakao Y, Matsumoto H, Miyazaki T, Mizuno N, Arima N, Wakisaka A, Okimoto K, Akazawa Y, Tsuji K, Fujita T (1981) IgG heavy-chain $(\mathrm{Gm})$ allotypes and immune response to insulin in insulin-requiring diabetes mellitus. New Engl J Med 304: 407-409

24. Kahn CR, Mann D, Rosenthal AS, Galloway JA, Johnson AH, Mendell $N$ (1982) The immune response to insulin in man: interaction of HLA alloantigens and the development of the immune response. Diabetes 31: 716-723

25. Keck K (1975) Ir gene control of carrier recognition. Eur J Immunol 5: 801-807

26. Barcinski MA, Rosenthal AS (1977) Immune response gene control of determinant selection. J exp Med 145: 726-742

27. Kapp JA, Strayer DS (1978) H-2 linked Ir gene control of antibody responses to porcine insulin. J Immunol 121: 978-982

28. Nagy ZA, Klein J 1981) The expression of Ir genes: macrophage or $\mathrm{T}$ cell - that is the question. Immunology Today 2: 228-229

29. Lee J, Trowsdale J (1983) Molecular biology of the major histocompatibility complex. Nature 304: 214-215

30. Sasazuki T, Kaneoka H, Nishimura Y, Kaneoka R, Hayama M, Ohkuni $H$ (1980) An HLA-linked immune supression gene in man. J Exp Med 152: 297s-313s

31. Lawley TJ, Hall RP, Fauci AS, Katz SI, Hamburger MI, Frank MM (1981) Defective Fc-receptor functions associated with the HLA-B8/DRw 3 haplotype. Studies in patients with dermatitis herpetiformis and normal subjects. New Engl J Med 304: 185-192

32. De Marchi M, Borelli I, Olivetti E, Richiardi $P$, Wright $P$, Ansaldi N, Barbera C, Santini B (1979) Two HLA-D and DR alleles are associated with coeliac disease. Tissue Antigens 14: 309-316

33. Betuel H, Gebuhrer L, Descos L, Bertrand J, Freycon F, Lepetit JC (1980) Celiac disease and its association with HLA markers. In: Terasaki PI (ed) Histocompatibility testing. UCLA Tissue Typing Laboratory, Los Angeles, pp 668-672

34. Gordon DS, Jones BM, Browning SW, Spira TJ, Lawrence DN (1982) Persistent polyclonal lymphocytosis of B lymphocytes. New Engl J Med 307:232-236

Received: 15 August 1983

and in revised form: 30 December 1983

Dr. W.G. Reeves

Department of Immunology

Queen's Medical Centre

Nottingham, NG7 2UH

UK 